\title{
ARTIG0S
}

\section{ANTECEDENTES DO HOMEM (*).}

A presença e o surgimento do ser humano na cena da História é, por necessidade, o ponto de partida do debate sôbre o Homem contemporâneo.

Ao mesmo tempo que indagava dos segredos do mundo que - rodeava, o Homem, o mais remoto no tempo e na precocidade de suas especulações, perguntava o que era êle mesmo e como viera a ser. Enquanto tentava adaptar-se à natureza, criando os meios de dominar racionalmente os demais sêres para sua segurança e sobrevivência, cogitava em sua própria origem e em seus destinos. As primeiras interrogações sôbre êsses mistérios foram respondidas pelo muito sôbre o comêço das coisas. Todos os povos primitivos tiveram ou têm ainda alguma estória explicativa da existência primeira do Homem, dos sêres sobrenaturais, das coisas e do mundo. Ao lado de outras características, êsses mitos têm uma função etiológica, que é uma espécie de história ontológica destinada a comunicar e a perpetuar as crenças sôpre a natureza e as origens da humanidade, sôbre a perfectibilidade desta e as suas relações com os outros sêres.

Os índios gê, do Brasil, acreditam que os homens foram criados pela Lua e pelo Sol, que são dois companheiros, ambos do sexo masculino, o sol mais importante, - o que ocorre na mitologia de vários outros povos primitivos da América. O sol e a lua criam a humanidade saltando para dentro de um córrego ou jogando, nesse córrego, cabaças que se transformam em sêres humanos. Os xerente, embora não tenham um mito antropogênico, chamam ao sol de "Nosso Criador". Maíra, que é uma figura sobrenatural tão importante na mitologia guarani quanto na tupi, se não criou os homens, ao menos criou o céu, a terra, os pássaros, os animais. Para os mundurucú, o mundo foi criado, a princípio sem os homens, por CarúSacaibê. Um dia, Daiiru, o tatú, ofendeu ao Criador e foi obri-

(*). - Reprodução de publicação da Universidade da Bahia (série III - 13.1961) (Nota da Redação). 
gado a esconder-se num buraco no chão. Carú-Sacaibê soprou para dentro do buraco e bateu o pé na terra. Daiiru foi empurrado para fora pelo vento e disse que havia gente debaixoda terra. Então os dois fizeram uma corda de algodão e a enfiaram pelo buraco. Os homens começaram a subir pela corda, mas esta partiu-se e uma parte da humanidade ficou debaixo. da terra e ainda lá está. Segundo outra versão do mito, o Criador bateu o pé no chão: os brancos, os índios e os pretos saíram. da terra, e êle tatuou os mundurucú ao seu modo; os brancos. e os pretos se espalharam; Carú-Sacaibê, então, ensinou aos mundurucú como plantar e usar a mandioca, o milho, o algodão e outras plantas.

A mesma idéia, de que os homens já existiam debaixo da terra, encontra-se entre os indígenas das ilhas Trobriand, da Melanésia: no comêço a humanidade vivia debaixo da terra e ali os homens tinham uma vida semelhante à atual, com aldeias, propriedades, clãs, diferentes grupos sociais com seus privilégios, magia, contos e estórias... Com tôdas essas prerrogativas, os homens saíram do fundo da terra e se estabeleceram sôbre esta com os mesmos direitos e poderes sociais e mágicos. Para aquêles indígenas, há na terra diversos buracos, - grutas, fontes, nascentes de córregos, montes de pedras, por onde saíram os primeiros casais, tomaram posse da terra e estabeleceram as primeiras aldeias (1).

À medida que o pensamento se foi sintetizando em uma filosofia, a indagação sôbre essa incógnita crescia em importância e assumia uma nova preeminência. As primeiras formulações metódicas daquelas perguntas foram as indagações da Antropologia como capítulo de uma Filosofia que começava por distinguir o Homem das coisas, do universo inanimado, dos demais sêres vivos e de Deus.

$\mathrm{Na}$ linha da tradição filosófica de que somos herdeiros, essas distinções começaram com os pensadores da 'Jônia, como Tales, Anaximandro, Anaxágoras e outros, autores das primeiras explicações racionais dos mistérios do cosmos e de tentativas idênticas de explicação da formação do homem, explicações, estas, que, por assim dizer, advinhavam o evolucionismo.

(1). - Cfr. Julian Steward, Fandbook of South American Indians, Washington D. C., Vol. 1, 1946, p. 553; Vol. 3, 1948, pp. 131, 281; E. Schaden, A Mitologia heróica de tribos inđígenas do Brasil. Ensaio Etno-Sociológico, Rio de Janeiro, 1959, p. 139; B. Malinowski, Magic, Science and Religion, and other essays, N. York, 1954, p. 111. 
No relato mosaico, o Homem surgiu de um ato criador de Deus, sendo formado do "barro da terra" e havendo recebido a atividade vital por meio de "um sôpro de vida no seu rosto" (Gênesis I, 27; II, 7). Livro religioso, não redigido em têrmos e conceitos científicos, a Bíblia ensina que o ser humano é animado por um princípio imaterial e substancial imediatamente criado por Deus, mas não é explícito sôbre o modo como o corpo do Homem foi formado. Não se havendo jamais firmado, de maneira positiva por parte de qualquer igreja cristã, uma interpretação daqueles textos, o problema do aparecimento da forma humana entre os demais sêres vivos, que o mesmo relato registra como anteriores no tempo, foi até há pouco objeto de fator de desencontradas doutrinas entre os crentes cristãos.

Ainda hoje cabe perguntar como, onde, de que maneira se formou o Homem. Tomemos êste ser em sua individualidade biológica, deixando por agora a questão sempre intrigante de sua natureza e mesmo de sua peculiar e específica posição entre os outros sêres, para interrogar os fatos a respeito daquele aspecto da sua existência. Não que possamos prescindir da dualidade fundamental de princípios que explicam a especificidade do humano.

A primeira pergunta a tentar responder é a relativa à posição e às relações do Homem com as outras criaturas vivas. E' indubitável que o Homem tem uma componente biológica e que, por sua biologia aparenta-se, assemelha-se où, mesmo, pertence a uma ampla categoria taxonômica - a dos mamíferos da ordem dos primatas. Uma das implicaçõos dessa idéia consiste em que é de tal modo peculiar essa biologia que não é possível tratá-la sem a qualificação de humana, por isso que é a única, realmente, condicionada, essencial e existencialmente, pela cultura e pela vida em sociedade. Uma realidade é, na verdade, a biologia da generalidade dos sêres vivos, - outra é a do Homem.

Da existência da atual forma humana, por outro lado, parece certo que não data dos primeiros dias da história da terra, nem mesmo da história da vida no globo. A espécie Homo sapiens, a que pertencemos, surgiu, provàvelmente, há mais ou menos trinta e cinco a cinqüenta mil anos, que é de quando datam os mais antigos esqueletos fossilizados, que se encontraram até agora, com os traços morfológicos atuais. O famoso homem de Cro-Magnon, cuja existência na Europa meridional é testemunhada por vários esqueletos completos, rea- 
lizava já o Homem contemporâneo em sua anatomo-biologia e: começava a criar a cultura de que hoje participamos. A época e o modo do seu aparecimento são problemas ainda a resolver definitivamente. $\mathrm{Na}$ verdade êsse tipo surge quase abruptamente em fase avançadíssimo do período pleistoceno, pouco anterior ao início do holoceno ou recente, que é a época da história da terra que estamos vivendo. Notemos que êsse tipo é coetâneo de alguns outros na Europa, em CombeCapelle, por exemplo, na África em Boskop e na Ásia nas camadas superiores da famosa gruta de Chucutian, China, todos participando de um conjunto de caracteres somáticos tais como o tamanho e a forma da caixa craneana, a dentadura, a forma da abóbada palatina, a contextura dos ossos, as proporções faciais e corpóreas, que são idênticas embora variem em tôrno de normas muito próximas das atuais.

Êsse tipo humano, sendo já o mesmo Homo sapiens de nossos dias, viria a modificar-se, dando origem aos estoques raciais hodiernos, os quais acabaram de delinear-se há uns 10 mil anos atrás, de acôrdo com as evidências paleontológicas; na Europa as variedades conhecidas estabeleceram-se em suas áreas geográficas típicas há cêrca de 6 mil anos, alguns tipos sendo mais recentes (2).

Como aquilo se processou, tentaram explicá-lo alguns paleontologistas, como Sergi, Klaatsch e Weidenreich, com a hipótese polifiletista; segundo essa teoria cada uma das grandes raças ou tipos raciais derivaria de uma linha ou phylum específico: os indígenas australianos, que constituem um tipo difícil de enquadrar nos esquemas clássicos de taxonomia racial, teriam sido precedidos pelo chamado Homo wadjakensis, e mais remotamente, por hominianos muito primitivos da série dos pitecântropos, sejam os Pithecanthropus soloensis, erectus e robustus, que viveram em Java, no sudeste da Asia, há pelo menos 500 mil anos; a raça amarela ou mongolóide, viria de um ramo iniciado com o Sinanthropus pekinensis, um pouco menos antigo do que os últimos; a raça brança estaria na linha do Homo neanderthalensis, mais recente no tempo e mais próximo do ponto de vista morfológico da variedade humana atual; os negros africanos, finalmente, seriam descendentes do Paleoanthropus rhodesiensis, contemporâneo, na Africa, do homem de Neanderthal. Cada uma dessas linhas remontaria por sua vez, a diferentes antropóides da superfamília

(2). - R. J. Braldwood, Prehistoric Men, Chicago Natural History Museum, Anthropology, n..$^{\circ}$, Second ed., 1951, p. 33. 
Hominoidea, não hominídeos: a raça caucasóide descendendo dos chimpanzés; a negróide, dos gorilas; a mongolóide, dos orangotangos. Originando-se de espécies 'e até de gêneros diversos, a humanidade seria constituída de espécies diversas e o H. sapiens representaria uma categoria supra-específica, incluindo, na opinião de Ruggles Gates, as raças atuais (3).

A hipótese polifiletista, todavia, não explica satisfatòriamente as variações que resultaram na formação das raças que conhecemos. Contra essa teoria milita, entre outros, o fato de que havia diferenças mais acentuadas entre aquelas ascendentes do que entre as raças vivas. A menos que resultasse de um surpreendente e improvável grau de convergência, isto é, de expressão fortuita de identidades não relacionadas genèticamente, o H. sapiens, na verdade, teria sido sempre uma única espécie e aquêles outros tipos não passariam de colaterais do mesmo tronco (4).

Seria leviano, apesar de tudo, supor encerrada a discussão do polifiletismo: há, por exemplo entre geneticistas, quem considere consistentes as razões par manter essa teoria (5).

Howell acredita, contra a opinião de Livingstone, que não há parentesco filogenético entre o Homem europeu e o norte africano do pleistoceno médio. Na Europa não haveria qualquer sinal da existência de pitecantropinos, tão freqüentes no sudeste da Ásia, e o único fóssil da época, o de Mauer, "é suficientemente diferente, a ponto de poder ser considerado tentativamente como especificamente distinto da linhagem lesteasiática"; entretanto as populações do nordeste africano (do Marrocos) seriam aparentadas com os asiáticos. Teríamos, assim, dois gêneros distintos: o Pithecanthropus e o Homo, respectivamente (6).

Uma outra hipótese, de índole monofiletista, atribui aquelas variações a um complexo de fatôres que se encadeiam assim: dispersão e isolamento de grupos humanos saídos de um núcleo inicial, e seleção natural no processo de adaptação aos novos nichos ecológicos; nessas circunstâncias, .o impulso genético ocasionaria, de modo acidental e não orientado, modi-

(3). - Apud J. Comas, Manual de Antropologia Física, México, 1957, p. 515.

(4). - William W. Howells, "The Distribution of Man", Scientific Amertcan, Sept., 1960, Reprint, p. 3.

(5). - William C. Boyd, Genetics and the Races of Man, Boston, 1950, p. 328.

(6). - F. Clark Howell, "European and Northwest African Middle Pleistocene Hominids", Current Anthropology, Vol. 1, n. ${ }^{\circ}$ 3, Chicago, 1960, p. 223; Frank Livingstone, Current Anthropology, Vol. 2, n.o 2, Chlcago, 1961, p. 117. 
ficações nas proporções dos genes presentes nas novas populações e, conseqüentemente, recombinações dos mesmos que se refletiriam no patrimônio hereditário e nos fenotipos resultantes da adaptação ao meio. Aos efeitos dêsses dois fatôres preponderantes e tanto mais eficazes quanto menores os grupos, somar-se-iam as mutações genianas e cromosômicas e, uma vez estabelecido o contacto entre as populações já diferenciadas, atuaria a mestiçagem. Partindo da ação, por assim dizer, fisiològicamente orientada da seleção natural, o processo se completaria por aquêles outros mecanismos biológicos e por mẹcanismos de ordem cultural e social como a seleção sexual por motivos estéticos e sociais que atuaram no passado como ainda hoje atuam em tôdas as sociedades.

Já no fim do período pleistoceno, insiste o geneticista Dobzshansky, o homem era uma única espécie diferenciada em vários tipos: a mesma dos nossos dias.

Não era, como hoje não é, um conjunto de espécies distintas, mas simplesmente uma espécie politípica. Materiais fósseis da Palestina, por exemplo, falam da existência, em época mais recuada, de possíveis mestiços de um tipo sapiens com o H. de Neanderthal, o que faz supor o aparecimento ainda mais precoce do primeiro. A menos que o $\mathrm{H}$. de Neanderthal estivesse sofrendo um processo de evolução para vir a ser o tipo humano atual, o que é admitido pelos especialistas que situam êsse tipo na linha ancestral do $\mathbf{H}$. sapiens, a presunção da mencionada miscigenação seria a mais plausível explicação das características do $\mathrm{H}$. do Monte Carmelo. $\mathrm{O}$ achado de materiais ósseos pleistocenos de formas pré-sapiens, em Fontechévade (França) e em Swanscombe (Inglaterra), complica o problema da procedência e formação inicial do Homem moderno, ao tempo que reforça a hipótese, já referida, da contemporaneidade de dois ou três tipos distintos, $-\mathrm{o} H$. de Neanderthal, o $H$. da Rodésia e o H. sapiens ou um seu precursor.

Quanto a êste, é conveniente indicar que os materiais fósseis encontrados, - fragmentos de calote craneana em Fontechévade e restos incompletos de occipital e de parieital esquerdo em Swanscombe, não são suficientes para conclusões seguras, na opinião de alguns paleontologistas. A própria classificação dos portadores dêsses materiais é objeto de controvérsia ou, ao menos, de reserva. A julgar pela época em que teriam vivido, - o terceiro período interglacial. êsses sêres poderiam ter sido ou antecessores diretos do Homem moderno, anteriores ao apogeu do $\mathrm{H}$. de Neanderthal, êste sendo o ponto de vis- 
ta de Vallois, Le Gros Clark e outros, ou, mesmo, uma forma esboçada de neandertalianos. Qualquer que haja sido a via de desenvolvimento das formas pré-sapiens e sapientóides, o processo de formação do Homem moderno recuaria a pelo menos 150 mil anos, a julgar pelos elementos fornecidos pela paleontologia e pela geologia histórica.

Antes de prosseguir na análise dos desenvolvimentos que culminaram na hodierna forma humana e que continuam já agora ao alcance do contrôle do próprio homem, abramos um parêntese para indicar sumàriamente alguns dados sôbre as raças humanas atuais. Estas são variações, comparativamente mínimas de um ser único: quando se põem em confrônto, de um lado os detalhes anatômicos, como a forma da cabeça, da face, do nariz e dos lábios, as proporções relativas dos membros e do tronco, a textura dos cabelos e sua distribuição, a côr da pele e outros traços em que se baseiam as classificações raciais clássicas, e de outro lado a constišuição e a morfologia do esqueleto, o tamanho, a estrutura e a função dos órgãos, os caracteres histológicos, fisiológicos e genéticos e mesmo os tipos de sangue, torna-se evidente a unidade, tanto morfológica e fisiológica quanto genética da espécie.

Um outro parêntese destina-se a registrar as dúvidas e dificuldades que essa verificação introduz na discussão da natureza biológica e da configuração conceitual das raças vivas. Os conhecidos antropólogos Garn e Coon sintetizam essa questão, estabelecendo, de início, o princípio aceito por taxonomistas e geneticistas - como Weidenreich, Mayr, Dobzhansky e outros, de que o gênero Homo é representado por uma espécie singular politípica, à qual pertencem tôdas as raças hodiernas ou outras categorias taxonômicas eqüivalentes. Não há, contudo, acôrdo quanto ao número dessas categorias nem quanto aos critérios para as suas classificações: é sabido que uns têm proposto dividir os homens em duas raças, outros em cinco, outros em raças, sub-raças e variedades que somam trinta e até duzentas unidades. O óbice fundamental a uma concordância são as divergências sôbre qual a unidade que deve ser rotulada de "raça": uns têm em mente unidades geográficas, que correspondem a estoques ou divisões de outros especialistas; ali a expressão "raça". engloba grandes grupos, enquanto acolá refere-se a subdivisões de conjuntos. O critério geográfico, adotado já por Lineu e por Blumenbach e admitido como elemento complementar por outros taxonomistas, diverge do uso do têrmo "raça", sobretudo em genética 
de populações, para designar uma população mendeliana, isto é; um grupo de indivíduos potencialmente capazes de se conjugarem sexualmente para a reprodução. Ésses dois conceitos; de um certo modo divergentes, podem ser combinados, esclarecem Garn e Conn, nos casos de populações humanas que têm semelhanças óbvias e estão contidas dentro de limites geográficos determinados: em tal caso configura-se uma "raça geográfica". Uma tal raça geográfica viria a ser, em conseqüência, um conjunto de populações tendo traços em comum como a alta freqüência de um grupo sangüíneo, e ocupando uma área territorial definida. No Homem, como em outros mamíferos de larga dispersão, êsses limites correspondem muitas vêzes a áreas continentais, já que mares, oceanos, cadeias de montanhas são barreiras mais efetivas às migrações e ao fluxo de genes do que rios, elevações pequenas e outros obstáculos menores (7).

As seis raças do esquema proposto por Boyd, com base na frequiência dos genes correspondentes aos tipos sangüíneos $\mathbf{A}$, $\mathrm{B}, \mathrm{AB}, \mathrm{O}, \mathrm{MN}$ e $\mathrm{Rh}$, coincidem com os continentes: um grupo europeu precoce, de existência hipotética, hoje representado pelo povo basco; um grupo europeu, ou caucasóide; um grupo africano, ou negróide; um grupo asiático, ou mongolóide; um grupo ameríndio e um grupo australóide (8) .

Mas não conincidem perfeitamente os continentes com as áreas de dispersão dos mencionados grupos; há discrepâncias a registrar, em vista da adaptabilidade excepcional e da mobilidade do Homem. Isto não prejudica, entretanto, o fato de que a unidade taxonômica imediatamente situada abaixo da espéciee é melhor definida como "raça geográfica". Em contraste com as raças geográficas, conjuntos ou coleções de raças-populações locais cujos membros marginais podem ser algo discutíveis, existem também as populações chamadas raças locais na mesma terminologia (9). Essas unidades são quase sempre isolados de populações relativamente pequenas que se distinguem não tanto por uma média de freqüência de certos traços fenotípicos quanto por seu grande isolamento. Essas raças microgeográficas são objeto de grande interêsse para o estudo dos problemas de filogenia das raças e de evolução

(7). - Stanley M. Garn and Canleton S. Coon, "On the Number of Races of Mankind", American Anthropologist, Menasha, Wis., Vol. 57, n.o 5, 1955, p. 996 ss.

(8). - Boyd, op. cit.' p. 268.

(9) . Gàn e Coon, op. cit., p. 997 
humana em geral. Diversos pesquisadores brasileiros se vêm dedicando à coleta de materiais e à análise de isolados determinados não apenas pelo insulamento geográfico como pela endogamia característica de grupos tradicionais da nossa sociedade; os seus achados, entre indígenas e entre populações civilizadas, contribuirão para a explicação dos fenômenos de diferenciação e de variações somáticas e fisiológicas, resultantes do impulso genético e da recombinação sexual.

À base dos raciocínios expendidos é possível estabelecer a existência atual de seis ou sete raças geográficas; se o conceito de população mendeliana fôr tomado como eqüivalente de raça local e de raça microgeográfica, o número de raças pode subir a mais de trinta. Reconhece-se claramente, na opinião dos dois autores citados antes, uma raça geográfica européia e asiática ocidental que se conforma à categoria "caucásica" do esquema clássico de Blumenbach. Há uma raça norte e lesteasiática, englobando um grande número de raças locais. Também uma raça africana e uma indiana. A micronésia e a melanésia, na Oceania, constituem uma categoria separada, da mesma maneira que a polinésia. Anatômicamente os aborígenes ameríndios parecem-se com os asiáticos mas sorològicamerite têm várias dissemelhanças.

Aí temos sète raças geográficas. Não é tão simples a caracterização e a fixação do número de micro-raças. Ainda estão em marcha os estudos que permitiriam conclusões a êsse respeito. Note-se contudo, que essas unidades ultrapassam o número de trinta. Certamente que a idéia de raças geográficas atende mais a uma conveniência pedagógica do que à caracterização de objetos para a investigação empírica.

Voltemos ao tema que nos ocupava. Se é sabido que o Homem moderno surgiu em época relativamente tão próxima, em têrmos da idade da terra e da antigüidade da vida nesta, as quais se estimam respectivamente nos mínimos de dois bilhões de anos e de cem milhões de anos, segundo os testemunhos bioquímicos e paleontológicos, também é certo que viveram outros sêres do gen. Homo antes da nossa atual :espécie. Como não tinham a mesma estrutura somática, embora fôssem sêres com as aptidões e as atividades próprias do ser social e cultural que é especificamente e exclusivamente $o$ ser humano, os naturalistas os têm categorizado como nonsapiens, ainda que hominídeos verdadeiros.

Já indicamos a contemporâneidade de supostos tipos présapiens e sapientóides com o chamado Homo neanderthalensis, 
que viveu sobretudo na Europa desde pelo menos a metade do período pleistoceno, há mais ou menos quinhentos mil anos. Os seus exemplares principais são os de Chapelle-aux-Saints, de Malarnaud, de Le Moustier, La Quina, La Ferrassie na França, o de Spy na Bélgica, os de Gibraltar e Bañolas na Espanha, os de Saccopastore e Monte Circeo na Itália, o de Krapina na Croácia, os de Tânger $€$ Broken Hill (Homo rhodesiensis) na África. Enquanto o H. sapiens é, morfològicamente e mesmo cronològicamente, um neântropo, um "nôvo homem", aquêle cutro tipo é, segundo os mesmos critérios, caracteristicamente um paleântropo ou, mesmo, o arquétipo desta categoria. Ainda que chegassem a viver, durante certo tempo, na mesma época e região, está verificado pelos testemunhos fóstempo que o $\mathbf{H}$. sapiens. Isto é o que nos indicam os dados paropa central e meridional, começara a existir há muito mais tempo que $\mathbf{H}$. sapiens. Isto é o que nos indicam os dados paleontológicos e também os materiais arqueológicos, isto é, os artefatos de uma cultura que surge em um nível muito próximo do em que se apresentam indícios daquele ser: refirome sobretudo aos instrumentos líticos da série musteriense. Convém fixar, todavia que êstes não são os artefatos e os instrumentos mais antigos e primitivos que se conhecem.

$\mathrm{O}$ denominado $\mathbf{H}$. neanderthalensis poder-se-ia considerar um hominídeo que não completara sua auto-domesticação, dado que a presente morfologia humana assemelha-se à de outros mamíferos domesticados; no caso humano, o processo de ajustamento e adaptação, a que se chama em biologia de domesticação, seria promovido pelo próprio ser humano para compensar a sua relativa inferioridade biológica em face dos outros sêres vivos e da natureza inanimada. Já consistiria, essa autonomia, num resultado e numa evidência de qualidades e da natureza especiais do homem, mesmo o mais antigo, como ser racional e criador de cultura, isto é, capaz de criar as condições para a sua existência. Conquanto, do ponto de vista taxonômico, se possa falar em pelo menos dois grupos neandertalianos, - um clássico e um precoce, o conjunto dos neandertalóides é grosso modo caracterizado por um crânio volumoso com o frontal algo deprimido e a abóbada baixa, arcadas supra-orbitárias salientes, mandíbulas largas, mento recedente, extremidades ósseas que não permitam uma postura completamente erguida; ao lado dêsses traços, morfològicamente primitivos, o grupo apresentava elementos tipicamente humanos na cabeça, na coluna vertebral, na pelve, e uma 
capacidade craniana entre 1.200 e 1.620 c. c., com uma média de 1.45 d c. c., superior à dos europeus modernos, que é de 1.400 c. c.

Embora faltassem ao tipo genérico do $\mathbf{H}$. neanderthalensis certos caracteres fenotípicos próprios do homem moderno, particularmente a procedência do mento, aquêle foi durante muito tempo considerado como a mais antiga forma humana, um Homo primigenius. Era, como já se assinalou, um grupo não uniforme, alguns de cujos exemplares tinham elementos sapientóides ou neantrópicos: assim sucede com os espécimens de Steinheim, de Ehringsdorf, da Galiléia e do Monte Carmelo.

Chegamos a uma verdadeira encruzilhada da filogenia humana. Estamos, de fato, em presença de um indubitável hominiano, muito embora bastante diferente do $\mathbf{H}$. sapiens. Tão chocantes pareceram êsses contrastes que, desde o achado dos primieiros exemplares fósseis dêsse tipo em 1859 até os primeiros anos do século corrente, houve sérias dúvidas entre os anatomistas, os antropólogos e paleontólogos sôbre a normalidade do portador da peça craniana de Neanderthal. Foi a coincidência de caracteres idênticos em numerosos outros crânios e em esqueletos mais ou menos completos, que forçou a conclusão de tratar-se de um verdadeiro hominídeo, anterior ao tipo moderno ou contemporâneo do surgimento dêste. A espessura e os diâmetros de alguns dos seus ossos, em especial a mandíbula, aparentam êsse hominídeo com um tipo algo mais antigo, representado pela conhecida mandíbula de Mauer, - o Homem de Heidelberg. Este, sem embargo do gigantismo de suas proporções, é inquestionàvelmente hominiano: os seus dentes são de tamanho muito maior do que os atuais, porém de morfologia hominídea. Para alguns especialistas, êste é um provável antecessor dos neandertalianos. Convém indicar que essa identificação, de um como de outro tipo, é feita por critérios morfológicos e também culturais: os materiais fósseis conhecidos, materiais que datam ainda do primeiro período interglacial, ocorrido há mais de 550 mil anos ou há algumas dezenas de milhares de anos mais perto de nossos dias, encontramse junto com instrumentos líticos de fabricação humana correspondentes à fase paleolítica inferior ou inicial.

Quando se afirma que esta é uma encruzilhada, tem-se em vista a controvérsia sôbre as relações do $\mathbf{H}$. neanderthalensis, em suas variedades assinaladas, com o H. sapiens. Não cabe nesta súmula entrar nas minúcias, tão complexas, do problema. Vale fixar, apenas, que uns consideram o homem de Neander- 
thal como uma espécie humana que se extinguiu, enquanto o $\mathbf{H}$. sapiens se originava do mesmo phylum; outros o enquadram na: linha filogenética do Homem moderno como um ancestral que, por adaptações sucessivas ou por mutações, se transformou no tipo atual (10). 'E' positivo que o $\mathrm{H}$. de Neanderthal desapareceu pouco depois do climax da última glaciação, há cêrca de 50 . mil anos, muito embora elementos fenotípicos do mesmo possam ser discernidos em sêres mais recentes e até em raças hodiernas como os indígenas australianos modernos, que têm, tanto na forma craniana e facial como nos membros e na arquitetura total do seu soma, traços que permitem supô-los herdeiros ou réplicas de um tipo neandertalóide.

\section{II}

A análise desenvolvida até aqui coloca-nos diante do fato de que o Homo sapiens não surgiu abruptamente no meio dos outros sêres, 'como faria crer uma interpretação estritamente literal da Bíblia, mantida por círculos cada vez mais restritos de fundamentalistas e há muito recusada, em sua formulação fixista, pela Igreja católica. $\mathrm{Na}$ encíclica Humani Generis, de 1950, o papa Pio XII afirma que, feita reserva do. dogma de fé que sustenta a criação da alma humana de modo imediato por Deus, a Igreja não se opõe à investigação e discussão da teoria da evolução do corpo humano como originário de matéria viva pré-existente, em outras palavras, de outros sêres vivos.

Já se mencionou, nesta exposição, a existência, anterior ao aparecimento do $\mathrm{H}$. sapiens, de artefatos e outros indícios da atividade de um ser inteligente. Viu-se que o homem moderno foi precedido ou, pelo menos, coetâneo de um outro hominídeo, de características próximas das suas, portador de traços primitivos, que alguns especialistas consideram pitecóides.

Como explicar, pois, a formação somática do Homem? Apesar de suas aptidões peculiares, específicas, e das diferenças qualitativas entre o seu psiquismo e o dos outros animais, mesmo dos antropomorfos mais evoluídos, o ser humano participa, sem dúvida alguma, do mundo biológico: do ponto de vista de sua morfologia e de sua fisiologia é um mamífero da ordem dos primatas. Os mamíferos săo vertebrados de san-

(10). - J. Comas, "La Evolución Humana", La Torre, México, 1957, sep., p. '108. 
gue quente que possuem um coração dividido em quatro câmaras, dois ventrículos e duas aurículas, respiram por pulmões, exibem pêlos sôbre o corpo e amamentam suas crias; os primatas têm, ademais, cérebros complicados e relativamente grandes, mãos e pés com função preensora ou claramente derivados de tipos preensores, ampla mobilidade dos dedos e oposição do polegar, unhas chatas em lugar de garras, e, ordinàriamente, a presença de apenas duas mæmas. Anote-se que o Homem faz exceção a algumas dessas características, particularmente quanto à locomoção e aos traços morfológicos correlativos: os babuínos e o Homem são, dos primatas, os únicos de hábitos não arbóreos, mas o último é o único de locomoção exclusivamente ereta.

As semelhanças do Homem para com os símios antropomorfos atuais cêdo foram notadas e têm sido objeto de especulação há dezenas de séculos. As primeiras explicações científicas dessas similitudes foram as de Haeckel, de Thomas Huxley, de Agassiz, de Charles Darwin - que se popularizaram sob a formulação falsa e simplista de que "o homem descende do macaco". A teoria fixista, que parecia até alguns decênios um corolário inevitável do criacionismo, resistiu muito tempo à admissão da idéia de que o ser humano atual não fôra criado em sua forma recente. À medida que os achados e os raciocínios de Darwin, relativos a outros sêres, se extrapolavam ao Homem e que aquêle naturalista e os seus seguidores extendiam seus conhecimentos ao ser humano, acumulavam-se as descobertas de materiais fósseis no sudeste da Ásia.e na Europa, os quais sugeriam a existência antiga de gêneros e espécies relacionados com o H. sapiens. Há pouco mais de um século, entretanto, teria sido tão impossível e chocante para o cientista sério falar, ou mesmo pensar em "homem fóssil", como há cinqüenta anos para a ciência oficial sugerir a mutabilidade do átomo (11). Mas a extensão da teoria da evolução a êste domínio, como um instrumento operacional de inteligência dos fatos observados pela paleontologia, pela anatomia e fisiologia comparadas, pela embriologia, pela genética, abriu novos horizontes à explicação do processo de formação dêsse ser único que é o Homem. O antigo esquema estático da taxonomia lineana foi sendo substituído pelo raciocínio de que, uma vez que os animais se propagam gerando outros animais, não era

(11). - Pierre Theilhard de Chardin, "The Idea of Fossil Man", in Anthropology Today, A. L. Kroeber, Chicago, 1953, p. 93. 
estranhável a hipótese ou a possibilidade de que os animais que mais se assemelhassem fôssem genèticamente próximos. A convergência de probabilidades e certezas promoveu, finalmente, a adesão dos biologistas à idéia da evolução. A paleontologia viria estabelecer uma sucessão de mundos biológicos diferentes, nos quais também o Homem tem um lugar. "A evolução é o único princípio que pode abranger essa cena cambiante, seguir os dramatis personae através das suas metamorfosiss, e dar sentido ao drama". Essa é a conclusão, já em 1950, de um eminente naturalista e antropólogo, sacerdote católico (12).

Estabelecido, assim sumàriamente, pela impossibilidade de dedicar mais tempo ao assunto, - o encadeamento do Homem moderno a outro hominiano e o seu parentesco biológico com os símios antropomorfos, recuemos o suficiente para verificar quando se evidenciam as tendências da evolução para a estruturação do futuro ser humano. E' necessário afirmar que logo que os conhecimentos sôbre as primeiras fases da formação somática do homem ou o roteiro percorrido pela família humana é ainda incompleto e envolve questões controversas. Sabe-se, contudo, mais sôbre essa questão do que sôbre a formação dos símios antropomorfos, isto é, os chimpazés, gorilas, orangotangos e gibões. A evolução do ramo primata que chamamos de "Homem" deve ter começado muito antes do que poderíamos ter sonhado. Essa é uma advertência de Weidenreich num pequeno livro que é uma síntese de seus pontos de vista (13). Segundo Le Gros Clark, "os biologistas concordam em que as várias formas vivas que estão agrupadas no esquema de classificação aceito como a ordem dos primatas, representam modificações divergentes de um tipo ancestral comum, e que o último derivou primàriamente de um tronco básico geral que também foi a fundação para o desenvolvimento de outras ordens de mamíferos. Dêsse tipo ancestral derivou em tempos geológicos remotos certo número de grupos distintos, cada um dos quais, inserindo-se na categoria dos primatas pelo seu comum plano geral de organização, incorporou tendências para a evolução por suas próprias linhas subsidiárias. Essas tendências culminaram no desenvolvimento de distintos padrões de caracteres estruturais por assim dizer superajuntados ao plano geral. De uma dessas subdivisões, nal-

(12). - J. Franklin Ewing, "Précis on Evolution", Thought, N. York, 1950, p. 67. (13). - F. Weidenretch, Simios, Gigantes y Hombres, Buenos Aíres, 1947, p. 30. 
guma fase do tempo geológico que ainda permanece incerta, surgiram os progenitores do Homo sapiens (14).

Efetivamente, já no período mioceno ou pouco depois, ainda no terciário, - há pelos menos 30 milhões de anos, começaram a surgir os verdadeiros símios antropóides: Dryopithecus da Europa, Sivapithecus da fndia, Proconsul da África e outros precursores dos antropomorfos vivos, a julgar pelos caracteres de suas mandíbulas e dentes; não apresentavam, contudo, uma aproximação definida para o tipo humano. Prenunciavam o gorila, o orangotango e o chimpanzé e reuniam-se numa categoria geral de driopitecíneos. Dêsse largo grupo descendem os pongídeos atuais e, é de crer, pelos dados conhecidos, os hominídeos: entre êstes estaria, a princípio, o Oreopithecus bambolii, da Itália, de crescente importância nos estudos da formação humana. Insere-se nesse passo o gênero Australopithecus, que só se vem a encontrar no fim do período plioceno, há mais de um milhâo de anos, - quando muito no início do pleistoceno, na éra quaternária, e que, por vários indícios, constitui um estádio muito provável do desenvolvimento da superfamília hominóidea que engloba as famílias pongidae, com os macacos antropomorfos, e hominidae com o gênero único de Homo e a espécie sapiens e suas predecessoras. Expondo esta seqüência em forma tão resumida, convém registrar as imensas dificuldades com que lutam os paleontologistas e anatomistas para estabelecerem as linhas centrais do processo de diferenciação daqueles tipos e de gênese dos mais recentes. A própria explicação das semelhanças entre aquêles símios extintos e seus sucessores, não é problema de solução fácil. E' óbvio, por exemplo, que mais seguro seria, para o raciocínio analítico, recuar a fases mais precoces do processo de formação dos primatas e das diversas radiações adaptativas que produziram seus três ou quatro ramos fundamentais: lemuróide, cebóide, cercopitecóide e antropóide. Isto pode ser dispensado numa discussão como esta.

E' na fase australopitecínea que parece assumir feição humana, por primeira vez, uma série de modificąões que se vinham verificando à medida da evolução dos simídeos catarrinos: a substituição do regime arbóreo de braquiação pela locomoção parcialmente bipedal, a transferência da habitação arbórea para a terráquea, a libertação dos membros anteriores para o uso exclusivo na preensão, a postura semi-ereta em vez da quadrúpede com as mudanças de forma da coluna vertebral e

(14). - W. E. Le Gros Clark, The Antecedents of Man. An Introduction to the Evolution of the Primates. Edimburgo; ${ }_{\text {; }}$ 1959, p. 2. 
da bacia, o retraimento da face e a redução do processo masticatório, a adaptação da dentadura a uma alimentação variada corn a redução dos caninos e outras alterações, o aumento da capacidade craniana e a expansão do córtex cerebral particularmente nas áreas frontal e parietal. Mesmo que não se possa asseverar que os australopitecíneos estão na direta linha de ascendência humana, aquêles exibem, em diversos dos seus exemplares fósseis como os de Taungs, Makapan, Sterkfontein e Swartkrans, da Africa meridional, vários caracteres que os fazem corresponder a um tipo intermédio aos símios antropomorfos $\epsilon$ ao homem: assim, a forma parabólica da arcada dentária, as proporções e morfologia dos dentes, a cabeça arredondada e volumosa, o alargamento do osso ilíaco, o estiramento da coluna vertebral, e outros.

$\mathrm{O}$ achado de esqueletos de pequenos animais, especialmente $\sigma$ achado de crânios fraturados e de ossos longos de outros animais com sinais de percussão numa das extremidades, amontoados nos sítios de ocupação dos espécimens referidos, contribuiu para fazer pensar que se tratasse de um antropóide que já usava francamente as mãos, tinha marcha bipedal e era caçador, - o que, tudo, parecia confirmar o seu alto nível de hominização. As coisas, porém, não são conclusivas e singelas: há muitas dúvidas a respeito das atividades dêsse primata e das suas relações morfogenéticas com a filogenia humana. Até há pouco duvidava-se francamente de que tivesse sido caçador; talvez houvesse sido, antes, caçado pelas hienas do seu tempo ou por outros mamíferos de porte avantajado. Não faz muito essa dúvida foi objeto de discussão por um dos mais autorizados paleontologistas dos nossos dias (15).

Uma descoberta de meados de 1959 , entretanto,-como que revoluciona os conhecimentos a respeito do Australopithecus. Louis e Mary Leakey, além de verificarem a associação de artefatos líticos com peças fósseis de um antropóide da parte mais recente do pleistoceno inferior de Tanganica, na Africa oriental, identificaram um nôvo gênero fóssil australopitecíneo, o Zinjanthropus boisei, cujo crânio tem elementos que lembram o Paranthropus robustus, que membro da subfamília australopitecídea, e outros traços que não ocorrem nesse grupo e que são muito mais próximos do Homo. E como para com-

(15). - S. L. Washburn, "Australopithecines: the Hunters or the Hunted", American Anthropologist, Menasha, Wis., Vol, 59, n.o 4, 1957, p. 612 ss. 
plicar a questão, êsse "nôvo elo na evolução humana", é mais antigo do que qualquer dos pitecantropinos (16) .

Essa aproximação como que abre caminho para um nôvo episódio de radiação adaptativa, que resulta num passo nítido para a homização. No período pleistoceno registram-se os primeiros materiais seguramente hominianos. Com os arcantropinos do gênero Pithecanthropus é que, realmente, se inaugura aquela nova série. Porém outros tipos intercalam-se nessa linha filogenética, identificados por materiais escassos - dentes e fragmentos de mandíbulas - e por indícios ainda discutíveis. Achados feitos no sul da China e em Java, por Koenigswald e outros investigadores, conduziram a incluir naquele segmento do phylum hominídeo o Meganthropus paleojavanicus e $o$ Gigantopithecus blacki. Se bem que a posição taxonômica dos portadores dêsses testemunhos seja duvidosa, êsses dois tipos têrn uma dentadura que os coloca ou na seqüência do phylum. ou, ao menos, em uma linha paralela muito próxima. Reparese, nesses exemplares, um caráter nôvo - que contrasta com os presumidos pré-hominídeos anteriormente admitidos, o gigantismo: os dentes são aproximadamente seis vêzes maiores do que os correspondentes no Homem e os ossos têm espessura e tamanho igualmente avantajados. Êsse gigantismo seria um caráter primitivo que vem a regredir com o tempo mas que ainda marcará sua presença em tipos posteriores, como na mandíbula de Mauer, que representaria o chamado H. de Heidelberg, e nos pitecantropinos.

Pithecanthropus robustus e $\mathbf{P}$. erectus, achados clássicos de Java, em Trinil e Sangiran, vêm a ser, realmente, os inauguradores de uma linhagem ou, pelo menos, de uma fase da hominização. Ésses săo os primeiros tipos que, identificados já por suficientes materiais, comparecem com formas e dimensões hominianas ou certamente precursoras do gen. Homo: as mais significativas dessas características são a capacidade craniana, que se eleva a uma média de 940 c. c., ou mesmo a 1.000 c. c., muito superior à dos maiores antropomorfos, P, em segundo lugar, a marcha em postura ereta. Os pitecantropinos surgem no pleistoceno inferior ou talvez no médio e assinalam-se por êsse cérebro volumoso e complexo, que já faz supor uma distribuição e um desenvolvimento dos centrus de associação idênticos aos do Homem, uma estatura e pê-

(16). - "The Newest Link in Human Evolution: the Discovery by L.S.B. Leakey of Zinjanthropus boisei. Leake'ys account", Current Anthropology, Vol. 1, n. 1 , Chicago, 1960, p. 76. 
so igualmente próximos aos humanos, a postura erguida com mircha bipedal exclusiva, o pleno uso das mãos com função. preensora. São formas gerontomórficas, de ossos espêssos, face protrusa, acentuadas arcadas supra-orbitárias, mas já de feição muito humana se as compararmos com os atuais antropomorfos; representam, por exemplo, uma considerável redução do maciço facial, das mandíbulas, dos dentes caninos e molares, das protuberâncias cranianas, das cavidades orbitárias e, assim, de outros traços que persistem nos grandes símios hominóides, particularmente no gorila.

Além dos espécimens de Trinil e Sangiran, que configuram. a forma típica dêsse gênero, outros exemplares, encontrados no leito do rio Solo e em Djetis, perto de Modjokerto, apresentam-se em Java, desde o pleistoceno inferior, como estádios de transição para as formas paleantropinas, ou como variantes dos mesmos arcantropinos. Estes, evidentemente, povoaram o sudeste da Ásia por volta do médio pleistoceno, há menos de 500 mil anos, no segundo período inter-glacial. Na verdade, forain encontrados em depósitos do médio pleistoceno dos arredores de Pequim, na China, materiais fósseis de algumas dezenas de indivíduos muito pròximamente aparentados com o Pithecanthropus, e a cujo tipo se denominou de Sinanthropus pekinensis. Neste Homem da China as formas são menos grosseiras e a capacidade craniana é um pouco maior, atingindo a uma média de quase 1.000 c. c., com extremos de 915 e de 1.225 c. c., de modo que parece tratar-se de uma raça geográfica, algo mais evoluída, do grupo pitecantropino. Êsse nôvo arciantropino, o Sinanthropus, incorpora nítidos progressos: a região frontal é mais abaulada, o crânio mais globoso e alto, além de mais volumoso, desaparece o diástema entre o canino e o incisivo, o seio frontal é menos amplo e o ocipital mais estreito e alongado; a mandíbula ainda sem a projeção anterior do mento, é, por sua vez, mais decaída em espessura e proporções.

Enquanto outros fósseis de Wadjak, em Java, e de Keilor, na Austrália, parecem estabelecer uma seqüência filogenética do Pithecanthropus com o hodierno indígena australiano, passando por $H$. soloensis e $H$. wadjakensis, $-o H$. rhodesiensis, junto com $\circ \mathrm{H}$. de Solo, por seus elementos sapientóides. podem estar nas mais remotas raízes do $\mathbf{H}$. sapiens.

Chegamos ao pleno domínio dos hominídeos non-sapiens, mas - até onde se pode inferir dos dados reunidos e da análise dêsses materiais - já humanos em sua morfologia. Natu- 
ralmente que a ordenação taxonômica dêsses tipos primevos continua problemática e a carecer de muitos mais esclarecimentos. E' verdade, contudo, que traços sapientóides e neandertalóides se esboçam por esta altura, predizendo e como que prenunciando o surgimento de novos tipos orientados para uma fenotipia pròpriamente humana.

Aos problemas de anatomia comparada e de paleontologia, que nesse passo desafiam os estudiosos, ajuntam-se os de datação das peças e dos terrenos em que estas são encontradas. Por muito que hajam progredido os métodos de datação de terrenos e rochas, sobretudo os que se baseiam na medida da desintegração de materiais radioativos, a exata fixação da idade dos estratos geológicos e dos fósseis é uma tarefa cheia de dificuldades e incógnitas. Acresce que a paleontologia tem complicados problemas no correlacionar os sêres que viveram nas diferentes regiões do globo, pois aqui uns se extinguiram numa época, ali viveram ainda muito tempo, acolá pouco se sabe da ecologia do período, e assim por diante. Difere a cronologia de continente para continente, do mesmo modo que diferem as suas faunas e climas numa mesma época. Tudo isto reflete-se na paleontologia humana, dificultando a interpretaçãa dos achados e a significação teórica dos mesmos.

Não é fácil, como se vê, delinear de maneira indiscutivel uma cronologia filogenética para o homem. Ademais, descobertas recentes na Africa oriental, introduzem novas incógnitas na questão: o Africanthropus njarasensis, encontrado por Kohl-Larsen, parece-se tanto com o Pithecanthropus e com o Sinanthropus, que sugere a existência de um foco de hominização no continente africano, fora, portanto, do clássico bêrço sulastático da humanidade. Isto, que poderia implicar em uma volta ao polifiletismo, seria uma fase africana do mesmo processo evolutivo iniciado na Ásia e extendido àquela região por migrações antropóides. Repare-se que os terrenos em que se acharam tais materiais são, aparentemente, do pleistoceno superior, - muito recente, pois, o que lança uma séria dúvida sôbre a posição filogenética do espécimen. Assim é que, enquanto uns vêem no Africanthropus certos elementos neandertalóides, outros chamam a atenção para suas afinidades com o Meganthropus, fazendo dêste e do primeiro membros do grupo australopitecíneo. Na Africa do Norte, na Argélia, o achado de outio tipo pitecantropóide ou, antes, australopitecíneo e megantropóide, o Atlanthropus mauritanicus, de Arambourg e Hoffstetter, torna a África o único continente em que se descobre 
tôda uma série de elementos sucessivos da filogenia humana: australopitecíneos, pitecantropóides, neandertais e H. sapiens (17):

As mandíbulas de Mauer, na Alemanha, e de Mont-Maurin, na França, representariam, no terceiro inter-glacial ou antes, uma linha de conexão entre o H. heidelbergensis e o H. neanderthalensis, preenchendo uma lacuna que está aberta e que, com essa interpretação, tende a desaparecer. Encontramos, neste momento, a outra ponta do fio que havíamos indicado no comêço desta análise. Com tôdas as suas incertezas, mas também com a riqueza de conhecimentos que a justifica, a filogenia hominiana fixa-se em uma seqüência que. mesmo não se devendo ainda afirmar direta e linear, decorre de um estádio australopitecíneo, que se diria pré-hominídeo ou para-hominídeo, através de uma fase de hominização de que são testemunhas os pitecantropóides e neandertalóides, ambos os grupos enquiadrados no gen. Homo, porém, do ponto de vista morfológien, ainda non-sapiens, e, finalmente, conclui-se em $\mathbf{H}$. sapiens há cêrca de 50 mil anos, no post-glacial.

Restringindo-nos ainda ao terreno meramente anatômico e morfológico, cabe fixar uma importante noção: o Homem é, possivelmente, uma forma relativamente conservadora de um tronco comum antropóide, de que teriam derivado também, modificando-se mais acentuadamente e em menor prazo, os símios antropomorfos. Que o Homem derivou do estoque primata numa data anterior à dêsses simideos parace quase certo, de maneira que a sua linhagem seria mais antiga do que se tem geraimente suposto. Wood Jones recua ainda mais a época e o momento evolutivo em que se esboçaram os primeiros traços conducentes à forma humana; em sua opinião não haveria comunidade de filogenia entre o Homem e qualquer dos primatas simídeos. Segundo êsse paleontologista o Tarsius, de Bornéu, Filipinas, Célebes, Sumatra e algumas ilhas do arquipélago da Malaia, um prossímio situado antes dos macacos platirrinos e catarrinos, seria o parente vivo mais próximo do homem e o ramo humano se teria separado diretamente dos tarsióides do Eoceno, no comêço do terciário, há cêrca de 20 milhões de $\operatorname{anos}(18)$.

Pondo de lado êste ponto de vista e voltando à filogenia mais aceita, é fato admitido que o ancestral comum de Pongidae

(17). - Comas, Manual, p. 466.

(18). - W. C. Osman Hill, "Man's Relation to the Apes", in Yearbook of Physical Anthropology, 1950, Ann Arbor, 1951, p. 112. 
e IIominidae era menos diferenciado e só teria de comum com gorila, chimpanzé, gibão e orangotango certos caracteres básicos. E' errôneo representar êsse tipo primevo como um dos antropomorfos atuais; pelo contrário, êle lembraria mais o Homem:

O processo biológico que teria desencadeado a evolução dos primatas antropóides em direção aos hominóides e ao único gênero hominiano, foi a troca da vida arbórea pela marcha no solo em postura vertical; isto teria acarretado a libertação das mãos e daria oportunidade ao cérebro de expandir-se em tamanho e complexidade. Daí seguir-se-iam, por seleção natural e por mutações, as modificações que produziram a diferenciação humana (19).

Façamos uma recapitulação dessa longa e obscura história ou, antes, dessa intrigante pré-história, tentando, ao mesmo tempo, compreender os seus fatôres naturais. E' sabido que os novos tipos biológicos surgem, por seus testemunhos fösseis, de maneira que pareceria súbita, se considerarmos a longa duração dos tempos geológicos. Acontece isto, ordinàriamente, em concomitância com perturbações ou mudanças notórias no meio. Com as alterações do relêvo e da composição e ordenaçāo dos terrenos e a emergência de nôvo clima coincide o aparecimento de novos tipos biológicos. Um nôvo tipo, ou phylum, que constitui-se de reduzido número de indivíduos, mesmo de um par, começa a expandir-se e a procurar um meio que the seja propício ao florescimento e à multiplicação. No nicho ecológico assim escolhido por seleção natural, adapta-se e passa a subdjvidir-se em subtipos que, uns se extinguem e são, via de regra, substituídos por formas próximas, e outros se estabilizam; êstes crescem em número de indivíduos mas concentramse em poucos gêneros e espécies satisfatòriamente adaptados. $\mathrm{O}$ mesmo processo pode prolongar-se por meio de radiações adaptativas secundárias e terciárias, que produzem novas diferenciaçōes. As semelhanças e identidades que então se verificam podem, porém, ter causa em fenômenos de convergência biológica: sêres não aparentados, ajustando-se ao mesmo meio natural, desenvolvem caracteres próximos mas não relacionados genèticamente. Isto, porém, não nega os fenômenos de evoluçäo.

(19). - J. Franklin Ewing, "The Synthetic Theory of Evolution", Jesuit Science Bulletin, 1952, p. 59; "Human Evolution", Anthropological Quarterly, Vol. 29 , n. 4 , Washington D. C., 1956, p. 95. 
$\mathrm{Na}$ ordem dos primatas uma radiação daquela natureza teria ocorrido no comêço da éra terciária, subdivindo a ordem em pelo menos quatro novas linhagens progressivas e fecundas, cada uma das quais experimentou radiações secundárias trinta e quarenta milhões de anos após, no mioceno. As quatro linhagens, ou sub-ordens, que se haviam diferenciado são as que ainda hoje constituem as duas sub-ordens de prossímios e de antropóides, subdividida a primeira nas infra-ordens de lemuriformes, lorisiformes e tarsiformes, e a segunda nas séries platirrina, com a superfamília cebóide, e catarrina com as superfámílias cercopitecóide e hominóide; esta ramificou-se em três famílias: a hilobatídea, com dois gêneros correspondendo atualmente ao gibão e ao siamang, a pongídea com os gêneros em que se enquadram o orangotango, o chimpanzé e o gorila, e, finalmente, a hominídea com o gen. Homo. E' a evolução dêste gênero que procuramos resumir.

Há algum tempo, entre 600 mil e 1 milhão de anos, registrou-se na terra uma fase de grandes alterações com o levantamento dos terrenos e a formação de novas cadeias montanhosas, a erupção violenta e freqüente de vulcões e uma queda intensa de temperatura ambiente. Ocorreram êsses fenômenos no hemistério norte mas os seus efeitos repercutiram em todo o globo. Grandès massas de gêlo começaram a acumular-se no polo norte e nas montanhas mais altas daquele hemisfério. Essas geleiras recobriram a Eurásia e o norte da América, expandindu-se quatro vêzes de maneira a formarem as chamadas quatro glaciações e as três correspondentes interglaciações, que são marcos de referência indispensáveis na descrição da préhistória humana; as glaciações são a base da cronologia da éra quaternária com a longa fase pleistocena e a recentíssima fase holocena ou recente, iniciada há cêrca de $25 \mathrm{mil}$ anos com o. último degêlo.

Nos últimos tempos do plioceno, ainda na éra terciária, terse-iam verificado modificações em antropóides do grupo australopitecíneo, que marcaram a progressão de que resultou a emergência do gen. Homo: dêsse estádio, assinalado, como vimos, pela presença de vários tipos de Australopithecus, originam-se, em linna reta ou colateral, os mais primitivos e arcaicos hominianos - os pitecântropos; a êstes arcantropinos seguemse us neandertalianos, cujo grupo, numeroso e variado, forma o conjunto paleantropino, e, afinal, o neântropo ou H. sapiens, do qual conhecemos exemplares tão antigos que seus esque- 
letos se encontram fósseis nos jazigos, e a forma moderna de que todos somos exemplares.

O processo dessa transformação verificou-se a partir de um foco na Asia, mas teve prosseguimento noutras partes do globo, particularmente na Africa, e não percorreu uma progressão unilinear através estádios uniformes. Isto é o que explica a presença contemporânea, em regiões distanciadas, de tipos em fases diferentes do mesmo processo de evolução e as diferenças no ritmo de emergência dos sucessivos tipos. Tamkém esta é a razão porque é tão difícil desenhar uma árvore genealógica única e estabelecer uma cronologia da evolução humana que seja válida para tôda a terra. Note-se que estas reservas não invalidam a unidade do processo: apenas referem-se às particularidades da sua ocorrência em várias partes da terra.

Exatamente em 1859, ao publicar The Origin of Species, Charles Darwin estendia ao Homem os efeitos evolutivos dos fenômenos de variação e seleção que operavam entre os sêres vivos em geral e que, sendo suspeitados ou conhecidos desde séculos, só então eram sintetizados em uma teoria científica. Desde então os estudos da evolução multiplicaram-se e acumularam dados que permitiram explicar as diferenciações dos antropóides através das idades e éras até os nossos dias. As sinteses de tais progressos, levadas a cabo nas comemoraçõe da publicação daquele livro, que é um marco altíssimo do saber científico, mostraram, todavia, que muitos e largos hiatos persistem no domínio dos conhecimentos da biologia, da paleontologia, da arqueologia pré-histórica; em virtude dos quais ainda não é possível falar com irretorquível segurança dos detalhes da evolução humana. O problema central, - de quando emergiu o Homem em sua plenitude e de como caracterizar êsse momento, continua, por assim dizer, aberto à discussão e à controvérsia.

Um dos critéiros clássicos para a fixação dêsse momento teri sido o volume cerebral, avaliado pela capacidade da caixa craniana: admitiu-se até agora o limite mínimo de 750 c. c. para o exercício das atividades mentais especificamente humanas, limite que está situado bem acima das médias e mesmo àas máximas dos antropóides não hominídeos mais corpulentos. A descoberta do australopitecídeo Zinjanthropus boisei levanta de nôvo essa dificultosíssima questão: êsse antropóide tern uma capacidade craniana de 600 c. c. e parece ser o fabricante e utilizador dos instrumentos de pedra existentes na mes- 
ma jazida. Se é certo, como muitos admitem, que o característico inicial do surgimento da humanidade é a capacidade de produzir e fabricar instrumentos, já teríamos nesse ente um completo ser humano. Na verdade, observa Ashley Montagu, uma criatura capaz dessa atividade criadora, ainda que meramente manual, é também capaz de idéias e símbolos para a comunicação com seus semelhantes. Mas, para A. Irving Hallowell tais capacidades manuais seriam ainda protoculturais e infra-bumanas. Entretanto, é geralmente admitido que tanto aquelas capacidades quanto à aptidão para a comunicação por meio de sinais e símbolos pressupõem a linguagem articulada, outro privilégio humano. Estas consideraçỗes fariam datar o aparecimento do homem da época em que existiu o referido australopitecídeo; êle mesmo, à luz dos dados paleontológicos e arqueológicos, possivelmente o primeiro homem (20) .

'I'eríamos, hipotèticamente, a partir dêsse ponto, ou, mais segiramente, a partir dos arcontropinos atrás descritos, passarido pelos paleantropinos, o caminho percorrido pelo Homem em seus desenvolvimentos até atingir a sua forma moderna. (Ver Fig. I).

Como um animal de forma apta às funções que caracterizam o Homem se tornou um ser pensante, continua para as ciências naturais uma incógnita, embora muitos naturalistas, desde Darwin e seus predecessores a Theilhard de Chardin, atribuam êsse prodigioso fenômeno à própria evolução orgânica. Cientistas de ineqüívoca orientação naturalista são unânimes em reconhecer que

"nem mesmo os antropóides, que possuem aproximadamente o mesmo equipamento fisiológico vocal que o Homem, são capazes de aprender a falar" e que a cultura, de que a linguagem é parte integrante, "difere profundamente de tudo quanto se encontra no nível subhumano" (21).

$E^{\prime}$ êsse o momento em que a palavra passa à Metafísica, porquanto a fixação da natureza e da origem do especìficamente humano é problema eminentemente metafísico para o qual a Ciência contribui mas não tem, por si mesma, a última palavra.

Tôda esta exposição, por causa de tais dificuldades, foi, como se pôde ver, cheia de condicionais, de ressalvas, de conjeturas, de fórmulas de prudência. Diz Linton que

(20). - Ashely Montagu, "The Cerebral" Rubicon": Brain Sise and the Achievement of Hominid Status", American Anthropologist, Menasha, Wis., Vol. 63, n.0 2, Part 1, 1961, p. 377.

(21). - R. Linton, ó Homem: Uma Introdução à Antropologia. São Paulo, 1943, p. 98 ss. 


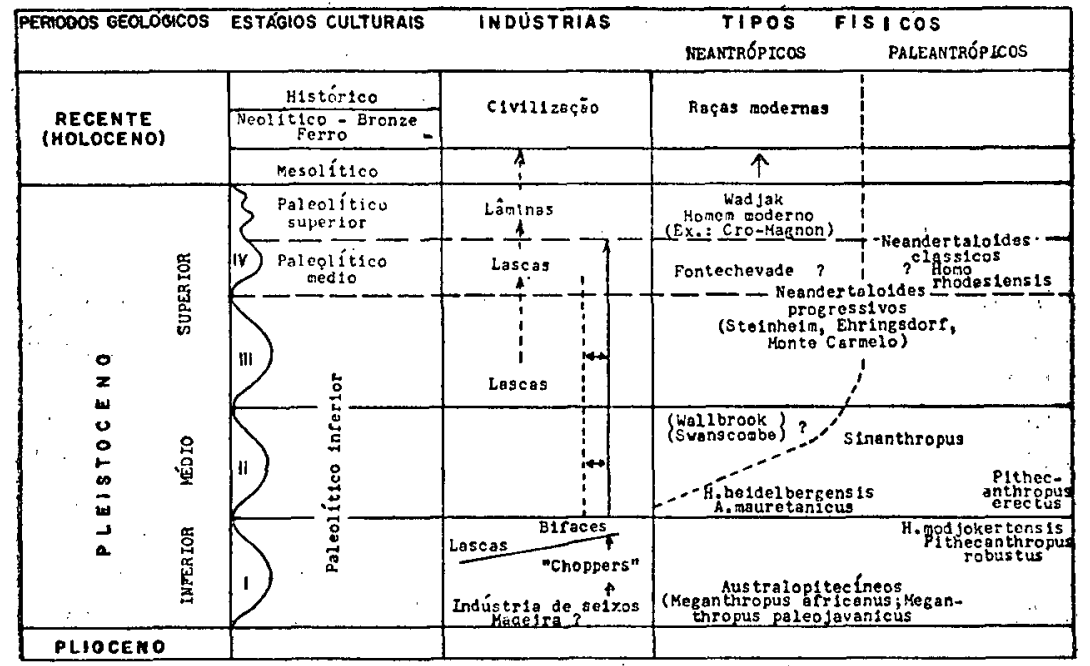

Fig.1 - Correlaçäo aproxinedo de períodos, cul turas, artefatos e tipos físicos, cfr. Eving, thath Evolution, p. 93. 
"quem quer que escreva sôbre a origem do homem deve usar liberalmente dos "provàvelmente" e dos "talvez" por isto que "há na documentação grandes lacunas, algumas das quais talvez nunca sejam preenchidas" (22).

Isto não implica, entretanto, em negar o processo da evolução, teoria que não contradiz a conceituação do Homem como um ser qualitativamente diverso dos outros sêres vivos, mesmo os mais evoluídos.

“E' uma teoria que põe em relêvo dinâmico a imagem do Homem, a corôa do universo material, com antigas e ancestrais raízes naquele universo material: o Homem, que pode legitimamente aspirar a irmão do anjo, òbviamente e pelo sangue é parente de todos os sêres vivos na terra criada por Deus" (23).

\section{III}

A caracterização de um australopitecídeo, seja por exemplo, o Zinjanthropus boisei, como primeiro verdadeiro ser humano, sugerida por L. S. B. Leakey e registrada apenas como umz hipótese a ser verificada, repousa, como já se viu, menos em dados da anatomia comparada e da paleontologia, do que em elementos arqueológicos que tenderiam a atribuir àquêle ser um gênero de atividades e aptidões, que, entre os sêres vivos, realmente só se encontra no Homem.

Esse atributo especificamente humano seria o "pensamento", isto é, a capacidade da inteligência dos conceitos, que se acompanha da linguagem simbólica e da acumulação e re-elaboração da experiência, e manifesta-se por atos inventivos que se condensam na cultura. Os indícios de cultura, com os quais a arqueologia ordinàriamente reconstrói a ambiência e as atividades de um ser, são, entre outros, os artefatos, isto é, os produtos da atividade criadora de utensilios mais os testemunhos de atos intencionais e culturais que se revelam na disposição dos objetos e dos corpos humanos e animais, do mesmo modo que plantas e outras matérias, associados numa jazida. Por meio de tipologias, cronologias e correlacionamento dos artefatos, corpos e meio, a arqueologia reconstitui situaçōes e as interpreta, a ponto de poder julgar da qualidade dos atos de seus autores.

(22). - op. cit., p. 35.

(23). - Ewing, Human Evolution, p. 122. 
Em se tratando de verificar quando se apresentam, nos mais remotos horizontes arqueológicos, os sinais ineqüívocos de presença humana, dois dificultosos problemas desafiam aos que jndagam empiricamente sôbre tais questões: - um é o de determinar quais os primeiros objetos utilizados com objetivos propositais, e quais os primeiros fabricados com os mesmos fins e furnçoes; outro é o de estabelecer que sêres empregaram e fabricaram tais instrumentos. Abra-se um parêntese para anotar que nada ou quase nada se sabe da possível utilização de peças de madeira e de outros materiais pereciveis como o osso, - marfim, há meio milhão de anos ou mais, quando se parecem ter formado os primeiros indubitáveis sêres humanos. O problema da existência do Homem na éra terciária não se esclarecei ainda, pela afirmativa ou pela negativa, - qualquer que sejam as informações da paleontologia, devido à insegurança dos aados relativos a testemunhos arqueológicos válidos (24).

A descoberta dos australopitecídeos trouxe a esperança de resposta à questão, ou do enigmático "elo perdido", ou do primeiro Homem, mas os problemas que levantou são maiores do que as luzes que trouxe. Esses antropóides fósseis têm sido encontrados junto com restos de pequenos mamíferos, especialmente cabeças com fraturas no crânio, e ossos longos de outros vertebrados com marcas de percussão em suas extremidades no lado de marcas de roedura. $O$ fato de não se encontrarem membros completos dos próprios australopitecíneos e de que as hienas e outros carnívoros acumulam os restos de suas caçadas nos abrigos a que se acolhem, complica imensamente a intcrpretação daqueles achados, mesmo quando entre êstes haja instrumentos líticos fabricados ou transportados. Tudo isto torna problemático o emprêgo dos mencionados instrumentos, líticos e ósseos, por êsse antropóide (25).

A hipótese de que os australopitecíneos fôssem antes caçados, do que caçadores, é, aliás, recusada por Dart; para êste paleontologista sul-africano,

"as únicas criaturas que se possam supor capazes de caçar australopitecineos com êxito eram vizinhos australopitecineos melhor equipados culturalmente" (26).

\footnotetext{
(24). - M. C. Burkitt, The old stone Age. A Study of Paleolithic Times, 3rd. ed., London, 1955, p. 103 .

(25): - Washburn, op. cit., p. 612.

(26). - Raymond A. Dart, "The Minimal Bone-Breccia Content of Makapansgat and the Australopithecine Predatory Habit", American Anthropologist, Menasha, Wis., Vol. 60, n. ${ }^{\circ}$ 5, 1958, p. 930.
} 
Ainda que ficasse evidenciado o uso do instrumentos em tais casos, faltaria um elemento para identificar êsse uso como. humano, isto é, a fabricação. Na verdade, com os australopitecineos do sul da Africa e de Tanganica associam-se seixos do leito dos rios, os quais por si mesmos pouco diriam quanto à sua utilização; todavia, êsses materiais parecem conduzidos delocais distantes, por não existentes nos sítios em que foram achados e, ao que parece, usados. Essa associação de ossos deantropóides com instrumentos não prova, de imediato, que ês-. ses animais faziam seus utensílios; talvez já os ultilizassem. Há. quem pense que um tipo humano desconhecido ainda, mas já presente naquele horizonte, pudesse ter sido o real usuário e, nalguns casos, o fabricante. O intrigante no caso é a associação de uso com manufatura numa época em que não há ainda provas anatômicas da emergência de verdadeiros hominídeos. (27):

$\mathrm{Na}$ verdade, com o Zinjanthropus encontram-se artefatos: líticis rudimentares da cultura ou série de Olduvai, - implementcs de tipo pré-Cheles - Acheul, de evidente fabricação. humana.

Nesta hipótese, ou aqueles "homens-símios" faziam seus instrumentos, ou êles mesmos seriam já humanos, desde quan-do essa capacidade costuma distinguir os hominídeos dos não-hominídeos. Linton observa, aliás, que existe um número sur-preendente de animais que usam instrumentos sem os fabricarem; é sabido que isto ocorre com o atual chimpanzé (28).

Atualmente intensificam-se nalguns grandes centros científicos, - em jardins zoológicos, em menageries especializadas.

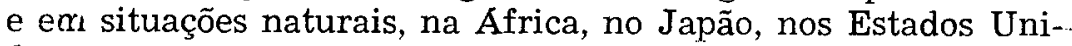
dos a outras partes, observações que vão levantando o véu que oculta o desenvolvimento e o desabrochar dos pré-requisitos. biológicos das mencionadas atividades e tendem a fixar o que. é pré-cultural em comparação com o humano e cultural (29).

Permanece o princípio, válido mesmo para os empiricistas. de orientação naturalista, que a diferença em relação aos sêres humanos é que êstes fazem seus instrumentos: em outras palavra:3, são capazes de antecipar, ou prever a situação em que o. instrumento será necessário e de se prepararem para a mesma

(27). - S. L. Washburn, "Tools and Human Evolution", Scientific American, Vol. 203, n. 3,1960 , reprint, p. 7 .

(28). - R. Linton in An Appraisal of Anthropology Today, Sol Tax, Chicago, 1953, p. 266.

(29). - Ver Kinji Imanishi, "Social Organization of Subhuman Primates in Their Natural Habitat", Current Anthropology, Chicago, Vol. 1, n. ${ }^{\circ}$ 5-6, 1960. 
situação. Isto indica o ponto em que a mente emerge, apta à reorganização da experiência pelo "pensamento" (30), momento culminante de um amadurecimento evolutivo em que, segundo Theilhard de Chardin, a natureza atinge as condições de especialização necessárias ao exercício do princípio intelectual que é o espírito, - exercício da indução, da abstração, da intuição no plano intelectual, e da liberdade e dos juízos de valor no plano moral. Já registramos que a criação do seu próprio ambiente, inclusive modificando o meio natural de mil maneiras, é o que caracteriza a cultura, em virtude do que o Homem pode ser definido, não sòmente filosòficamente mas mesmo do ponto de vista de uma ciência natural empiricista, como um animal que tem e cria cultura: e isto lhe é peculiarmente exclusivo (31).

Continuemos a argumentar, embora, assim, circularmente, não desenrolando a exposição em marcha unilinear mas aproveitando as ocasiões para ir esclarecendo certas questões à medida que estas surgem e retomando, depois, o rumo traçado de inicio.

Se por um lado o Homem é o único ser capaz, não de apenas aproveitar-se de instrumentos já existentes, mas de fazer, fabricar, modelar com suas mãos, segundo um plano intelectualmente concebido, os utensílios de que necessita, é também sabido que êle se utiliza, hoje como no mais remoto passado o deve ter feito, de materiais oferecidos pela natureza em forma original: seixos, fragmentos de rochas, ossos, dentes, espinhos, fibras, resinas, barro, etc. Muito antes de quebrar ou talhar a pedra e de usar outros materiais, é provável que os primeiros honiens multiplicassem a fôrça de seus punhos, para quebrar côcos e nozes, para triturar raízes e blocos 'de terra, para caçar pequenos e grandes animais, valendo-se de pedras, em estado natural. Ainda hoje o faz.

E' óbvio que a preferência, em muitos casos, havia de recair $\in \mathrm{m}$ pedras que fôssem achadas já com determinado formato, racilitando o manuseio'e aplicação dos golpes. Desde quando materiais dessa ordem foram aproveitados por um ser pensante, ainda não se pode afirmar com inteira segurança. Nem se pode ainda assegurar quando começou o fabrico de artefatos líticos rudimentares, de formato muito próximo dos naturais. Durante muito tempo os chamados eólitos, ou pedras dos pri-

(30). - Linton, loc. cit.

(31). - Kenneth P. Oakley and William Straus Jr., in An Appraisal of Anthropo. logy Today, p. 262. 
meiros tempos, foram os únicos utensílios feitos pelo Homem ou atribuídos ao Homem. Onde se encontram êsses eólitos junto com fragmentos de pedra evidentemente resultantes do trabalho com blocos maiores, de que os primeiros foram extraídos por métodos especiais de percussão, supõe-se a atividade humana. Assim, os pitecantropinos são identificados como hominídeos tanto por suas características anatômicas, que ainda diferem muito das do Homem moderno, quanto pela associação de seus restos fósseis com instrumentos daquele tipo, com vestígios de produção e uso do fogo, de atividade venatória, de dieta carnivora, de habitação permanente em cavernas, de vida gregária e social, de cultura, em suma. Por êsses indícios verifica-se a sua completa adaptação ecológica, isto é, a cabal integraçäo ao meio natural por parte de um ser que, menos dotado somática e fisiològicamente do que os demais sêres do seu tempo, já tinha uma qualidade nova, que lhe permitia a descoberta e invenção de técnicas de adaptação, a interpretação dos fenômenos da natureza, a comunicação da experiência aos seus contemporâneos e sua transmissão aos descendentes, a submissão a normas de convívio e até a concepção de uma sobrevivência ultra-temporal.

A partir aproximadamente do primeiro período interglacial, o período de clima mais ameno entre a 1a. e a 2a. glaciações, em que seguramente o gen. Homo já existia, até um período que dista de 100 a 70 mil anos dos nossos dias, as indústrias líticas foran representadas nas jazidas pré-históricas por dois tipos de artefatos, ou por dois estilos ou tradições. Supôs-se durante muitto tempo que um tipo teria precedido ao outro em seu aparecimento; hoje sabe-se que foram contemporâneos na Europa, embora não se possa estabelecer exatamente a mesma correlação noutras partes do mundo. Tratava-se, primeiro, dos chamados "machados manuais", bifaces, piriformes, que se produzian destacando pedaços da superfície de um bloco, por isto denominado de "núcleo", até que êste se reduzisse ao mencionado instrumento em um dos quatro ou cinco modelos conhecidos; segundo, das lascas de bordos grosseiramente cortantes que se obtinham fraturando um bloco maior. Aquêles famosos "machados manuais" tinham bordos ou contornos cortantes e uma ponta, e serviam de machado acionado a mão, sem cabo, como serviam de faca, de cutelo, de furador, de picador. As lascas eran mais delgadas e afiadas, servindo para cortar, talhar, raspar. Êsses dois tipos de utensílios estendiam-se da Europa à Ásia ocidental e à Africa. A primeira classificação tipológica 
dêsses materiais foi feita à base dos materias desenterrados na Eurupa e correspondem a duas linhas de desenvolvimento que, grosso modo, se resumem nos estilos abbevilense e acheulense para as indústrias de núcleos bifaces e nos estilos clactonense e levalloisense para as lascas. No sudeste da Ásia encontrava-se, um ijpo de entalhadeira ou enxó de mão, conseguida pela fratura oblíqua de um núcleo de forma alongada, de modo a obter-se uma aresta cortante. Diferindo, embora, em formato e maneira de obtenção, êsse instrumento tinha as mesmas utilidades dos bifaces europeus.

Correspondendo, na Europa, ao surgimento do H. de Neandertnal, assinala-se uma mudança que consiste em novas técnicas de modelagem dos mesmos instrumentos anteriores. As indústrias dessa fase, a musteriense, que caracterizam o paleolítico médio, são representadas por uma espécie de punção, ou furador, e por um raspador, ambos feitos de núcleos e lascas pequenos, retocados de um só lado. Além de outros elementos, produzem-se nessa época em forma de fôlha e pequenos discos; persistem os antigos machados de mão, mas tanto êstes quanto outros utensílios apresentam indícios de adaptação ao emprêgo por meio de um cabo de madeira fendida.

Entre 100 e $70 \mathrm{mil}$ anos atrás enceta-se um nôvo período que coincide com a chamada idade da rena e com o aparecimento do H. sapiens. Do ponto de vista lítico caracteriza-se pela fabricação e uso extensivo de um nôvo tipo de instrumento, as lâminas delgadas de sílex que se podiam afiar, arrancando-lhes uma camada do bordo cortante; serviam como buris ou cinzéis delicados e precisos. Essas lâminas vão sendo contìnuamente aperfeiçoadas e revelam um admirável virtuosismo dos seus fabricantes. Diminuem em tamanho e espessura, de modo a receberem dos especialistas a designação genérica de micrólitos. $\mathrm{Na}$ Africa do Noroeste por exemplo, produziram-se micrólitos triangulares, trapezóides, semi-lunares, que se engastavam ao longo das bordas de uma peça de osso ou de madeira para servir de arpão farpado; prestavam-se também para pontas de flechas, perfuradores e cinzéis de escultura. Desaparecem os bifaces, e o osso, que apenas era aproveitado sem modificações no paleolítico médio, agora é trabalhado e adquire tal importâr.cia que, em certas etapas dessa fase, se pode falar de uma "civilização do osso". Fabricam-se agulhas, facas, arpões, anzóis, pontas de lanças, raspadores tanto de osso quanto de marfim. Muitos dos instrumentos dêsses materiais eram ornados com desenhos entalhados, uns figurativos, outros convencionais. 
A arte animalista tem algumas de suas primeiras expressões nessas gravuras, como em modelagens e esculturas. As represertações da figura humana, particularmente sob a forma de mulheres ou de Venus com a acentuação das características sexuais secundárias, como nádegas e mamas e, por vêzes, ventres de grande volume, marca também o seu início com pequenas estatuas, algumas famosas pelo seu poder de expressão, - como as de Willendorf, na Austria, de Kostienski, na Rússia, de Lespugne, na França, sugerindo algumas intenção mágica ou ritual ou, quiçá, simplesmente estética do artista e da sociedade de então: essas estatuetas seriam, talvez, amuletos de fertilidade ou objetivações de um culto à maternidade e à procriação. Levantam, ademais, problemas técnicos e estéticos de estilos, de realismo e convencionalismo que se combinam com predominância do figurativismo. As representações humanas como as de animais reproduzem-se, por outro lado, em baixo relêvo e em pintura a côres nas paredes das cavernas do sul e do leste da Europa e do norte, centro e sul da Africa, revelando um acentuado interêsse pela arte e uma importante função dêsse tipo de expressão estética na magia, na religião, no convívio social.

Esse Homem do paleolítico superior foi o primeiro a produzir, além dos seus aperfeiçoados instrumentos de trabalho, obietos carentes de "uso", o que já configura a vigência de uma ordem social, econômica, política e espiritual bastante diferenciada com uma divisão de trabalho que incluia o artista, o artesão, o técnico especializado ao lado de outras categorias ocupacionais (32).

Ésses adiantamentos foram o resultado de cêrca de $250 \mathrm{mil}$ anos de nomadismo, de abrigo em cavernas, de exploração aventurosa da natureza, de uma economia de caça e coleta, da agregação em grupos pouco numerosos durante o período final do paleolítico. As indústrias dêsse período, como as dos anteriores, diferenciavam-se, segundo as épocas e as regiōes, em estilos e linhas de tradição estética e técnica; na Europa registram-se, em têrmos gerais, três fases e tipologias, - a aurinhacense, a solutrense e a madalenense, a última famosa por sua arte artística, documentada particularmente nas pinturas coloridas das cavernas da França, da Espanha, do Oriente próximo e da Africa, - de artes plásticas monumentalistas e de alta mestria, que transmitem aos nossos tempos uma ri-

(32). - A. Houghton Brodrick, E1 Hombre Prehistorico, México-Buenos Aires, 1955, p. 355 . 
"queza imensa de informes sôbre o pastoreio, a caça, as lutas - entre grupos humanos, a atividade dos sacerdotes, a fauna e outros elementos do meio na época, sôbre a organização social e econômica e as preocupações dos homens e os recursos que - dispunham para viver. A disposição das sepulturas, a posição dos esqueletos, os adornos e pinturas aplicados aos corpos sob a forma de colares, braceletes, corantes, falam das idéias religiosas e do cuidado com os mortos, os quais, por outro lado continuavam com suas famílias, enterrados no solo da própria habitação.

Há cêrca de vinte mil anos processa-se uma transição, através da fase chamada de mesolítico, com a qual se inicia o período recente. E' o tempo dos micrólitos engastados em lanças $€$ dardos de madeira e de osso, e dos seixos pintados com desenhos geométricos de significação ainda não bem determinada, precursores possíveis do alfabeto e dos algarismos. As industrias de osso declinam com o desaparecimento de sua melhor fonte de abastecimento, os mamutes e as renas, que recuam para o norte com as geleiras e entram em extinção. Coincidem com as grandes modificações do meio, em vista da cessaçãa da última glaciação, certa decadência nas expressões -estélicas e a emergência de novas formas de vida, resultantes, náo sòmente dos desafios da natureza mas provàvelmente de uma maturação da experiência humana. Onde havia geleiras surgiram florestas; formam-se novas ilhas; um dos animais que desaparecem, tanto pelas mudanças de clima quanto pela atividade dos caçadores, é o rinoceronte lanoso; animais menores e mais rápidos estimulam novos métodos de caça. Aproximadamente durante dez ou doze mil anos aceleram-se as mudanças nas esferas adaptativa e associativa da cultura, preparando a plena eclosão de uma nova fase.

Foram as mudanças relacionadas com o declínio das geleiras que permitiram novas migrações à procura de melhores condiçcies de vida e de autonomia para as populações. Mais ou menos por então, há cêrca de trinta mil-anos, grupos de mongolóides encetaram o povoamento da América, migrando através do estreito de Bering e ocupando, em ondas sucessivas, uma das regiões em que a cultura, a partir de então, teria várias fases de desenvolvimento autônomo, idêntico ao que se verificou no Oriente próximo e de que derivou diretamente a civilização européia.

O povoamento e a formação das culturas do continente americano continuam cheios de dificuldades, apesar dos pro- 
gressos da arqueologia, da botânica pré-histórica e da etnografia dessa parte do mundo. As dúvidas começam nos grandes hiatos entre a pré-história do Ocidente e a do Extremo Oriente e continuam na escassez de materiais pròpriamente americanos, particularmente a escassez de elementos paleontológicos relativos ao Homem.

Voltando à consideração do processo geral de formação da cultura, registre-se que

"a chegada da plena época neolitica é marcada por quatro novas descobertas que modificam profundamente tôda a vida humana: o homem havia aprendido a praticar a agricultura, a domesticar os animais, a fabricar a cerâmica e a polir seus instrumentos de pedras" (33).

O polimento da pedra permite produzir instrumentos mais afiados, com o que origina-se a carpintaria. Amenizado o clima e verificadas novas possibilidades de exploração da terra e dos recursos oferecidos por esta, os homens deixam as caveinas e grutas em que se abrigavam e se estabelecem junto às suas lavouras; estruturam-se os primeiros núcleos sedentários à margem dos rios e lagos, no fundo dos vales férteis, nos oasis, nas planícies aluviais. A revolução agrícola permite o armazenamento de estoques alimentares, a criação de animais para consumo e para o transporte, a regularidade da alimentação, a construção de casas e, com êsses progressos, uma nova divisão do trabalho social e das ocupações, uma organização política, econômica e eclesiástica complexa, o crescimento demugráfico, a ocupação permanente do solo.

Embora êsse período se haja denominado de neolítico, realmente não ostenta nenhuma inovação marcante na sua tecnologia lítica: é sabido que o polimento da pedra e o afiamento de facas e cutelos de osso já se faziam em épocas anteriores. $O$ que caracteriza, em verdade, essa nova época é a produção de alìrientos pela domesticação de plantas e animais sob o contrôle humano. Isto permitiu ao Homem de então deixar de ser um predador, um parasita da natureza; agora êle dirige e orienta, ao menos em parte, a produção dos seus artigos de consumo e isto the abre perspectivas e caminho para inesperadas conquistas (34).

(33). - Burkitt, op. cit., p. 244.

(34). - Kroeber, Anthropology, N. York, 1948, p. 688; V. Gordon Childe, "Old World Prehistory: Neolithic", in Anthropology Today, p. 193. 
Os primeiros êxitos das novas atividades econômicas registram-se, até onde se pode inferir dos achados arqueológicos, no denominado "crescente fértil" do sudoeste da Asia, entre o Gôlfo Pérsico e o Mediterrâneo, nas terras e montanhas do Irã, do Iraque, da Síria e da Palestina; mais tarde fenômenos idênticos ocorrem na China e, provàvelmente de modo independente, no Nôvo Mundo. Naqueles focos iniciam-se a seleção, o cultivo e o beneficiamento da cevada, do trigo, do milho, do arroz, da cana de açúcar, a domesticação da cabra, do porco, do cão, dos ovinos, muares e bovinos; com a caça e a coleta, que persistiram, e com os novos recursos tecnológicos a dieta humana se diversifica e torna-se regular, permitindo melhores condições de saúde e o incremento demográfico. Das melhorias tecnológicas merecem menção o arroteamento e a irrigação do solo, o cozimento dos alimentos, a moedura dos grãos, a ordenha de caprinos e ovinos, a pesca com armadilhas e rêdes, o beneficiamento do couro para vestuário e outras utilizações, o trabalho com a madeira (35).

As pequenas hordas erráticas estabilizaram-se e concentraram-se em lugares propícios às novas atividades, construindo grandes casas, espaçosas, subdivididas em diversos cômodos, feitas de adobe, taipa, pedra e madeira; essas habitações eram mobiliadas com camas fixas, mesas e outros móveis e serviam de residências comunais que juntas abrigavam de 100 a 600 pessoas em um só núcleo. Túmulos, templos, amuletos de pedra e de marfim, estatuetas femininas de barro crú ou cozido, de osso, de marfim, pedra e outros materiais falam de uma arte mais simbolista do que figurativa, da magia, da religião e dum sistema complexo de crenças daqueles primórdios da hodierna cultura.

O panorama aqui delineado de maneira esquemática e sumária não era uniforme no ecúmeno da época nem se configurou através das mesmas sequiências de ciclos, de estádios ou de complexos culturais. O que em algumas partes foi gradual e espontâneo, autóctone evolver de experiências, noutras resultou de importações ou de aculturação por contactos humanos, de tal maneira que mal se pode falar de um único período neolítico. A invenção, a descoberta, a difusão dos novos elementos culturais são, por sinal, um dos mais complexos problemas da Antropologia hodierna e o ponto de parti-

(35). - Braidwood, op. cit., p. 94; "The Agricultural Revolution", Scientific American, Sept, 1960, reprint, passim. 
da das teorias sôbre a formação e a expansão da cultura em geral (36).

Segundo Gordon Childe, o que o neolítico realizou de positivo foi a criação de uma economia rural com uma tecnologia adeqüada e, provàvelmente, uma concepção das coisas que permitia a adaptação a variados meios.

"A adaptação no Oriente próximo foi tão boa que sobreviveu sem modificação radical até o advento da mecanização; nas zonas florestais temperadas só se conseguiu um ajustamento durável, mais tarde, na idade do ferro. Ao mesmo tempo, uma separação entre tribos mais pastorais e lavradores sedentários começou seguramente na Europa, e noutras partes, provàvelmente, no curso do neolítico, embora as formas clássicas de nomadismo pastoral, baseadas no cavalo ou no camêlo, só se desenvolvessem depois. Os agricultores neolíticos descobriram e começaram a exploração da maior parte das melhores terras agrícolas, - mas não, por exemplo, dos ricos solos argilosos da Inglaterra, de muitas fontes de matérias primas e das principais rotas de migrações e comércio em terra e no mar. Inventaram formas satisfatórias de habitaçôes rurais, que persistiram nos seus respectivos meios até hoje, npenas modificadas por subseqüentes desenvolvimentos urbanos. Final.nente, os agricultores neolíticos devem ter descoberto os segredos da metalurgia e no Oriente próximo devem ter iniciado a organização para a efetiva aplicação daqueles segredos. Na Europa, contudo, embora se alcançasse o conhecimento técnico, - a máquina distribuidora, igualmente essencial para a economia da idade do bronze, só se aperfeiçoou com o auxilio ulterior do Oriente próximo" (37).

Do neolítico para a idade do bronze a passagem é gradual. No fim daquele as populações litorâneas da Europa ocidental construiram os famosos megálitos, complexos de peças quase gigantes que surgem na Península Ibérica com funções rituais e funerárias: os dolmens, menhirs, cromlechs, e se difundem para o noroeste do continente.

Enquanto isto começam a mineração e a metalurgia do cobre com a produção de armas e utensílios recortados no metal com formas e estilos ainda neolíticos com o desenvolvimento da fundição progridem essas indústrias para estilos pró-

(36). - Cfr. Munro S. Edmondson, "Neolithic Diffusion Rates", Current Anthropology, Chicago, Vol. 2, n.0 2, 1961, p. 71 ss.

(37). - Childe, op. cit., p. 208. 
prios e para a fabricação de novos utensílios. Também o ouro é descoberto e trabalhado, particularmente em joalheria.

"Quando, cêrca de 4.000 a. C. ou pouco depois nesta parte cis-Oriental do mundo, aparecem a verdadeira metalurgia e o bronze, é com o acompanhamento de adiantamentos ainda maiores: carros de rodas em disco, puxados por bovinos ou muares, o disco giratório horizontal que acelera a manufatura cerâmica, estruturas de templos, isto é de habitações para os deuses, objetos de valor como os vasos de alabastro e os primeiros espécimens conservados de sinetes, conformados mais ou menos como botões. Antes de 3.000 a. C. encontramos na baixa Mesopotâmia montículos construídos, suportando estruturas religiosas, templos de mais de sessenta metros de comprimento, e cidades cobrindo centenas de acres. O trabalho exigido para tudo isto só poderia ser feito por uma população de bom tamanho e bem coordenada. Havia os que davam ordens e os que as seguiam: governantes e governados, em suma; classes siociais diferenciadas, - sacerdotes, os ricos ou os nobres, governantes, talvez reis, ou ao menos aqueles cujos descendentes viriam, dentro em pouco, a governar como reis" (39).

A revolução urbana é a etapa seguinte, caracterizada pela formação de grandes concentrados urbanos, pelo surgimento dos Estados e das milícias guerreiras, pelo aparecimento das indústrias do ferro, da escrita ideográfica e do alfabeto. São as vésperas da época histórica. Um dos focos de tais desenvolvimentos é uma área que engloba a Mesopotâmia e o Egito, parecendo resultado da resposta cultural ao desafio de meios necessários à exploração agrícola mas carente de muitas das condições para isso.

Enquanto a pequena agricultura ou horticultura individual e familiar encontrava condições para prosperar nas encostas das bacias fluviais, onde as chuvas eram suficientes, -0 aproveitamento das terras aluviais nas margens e deltas do Tigre e do Eufrates, na Mesopotâmia, e do Nilo, no Egito, requeriam esforços conjugados, uma ação disciplinada e técnicas construtivas para o escavamento de canais, o alevantamento de diques, o represamento da água em açudes de modo a regular as enchentes e inundações, fazendo a água dos rios servirem às necessidades das populações. E' dêsse esfôrço em comum nas obras hidráulicas de proteção do solo e de regadio das cul-

(38). - Kroeber, op. cit., p. 705. 


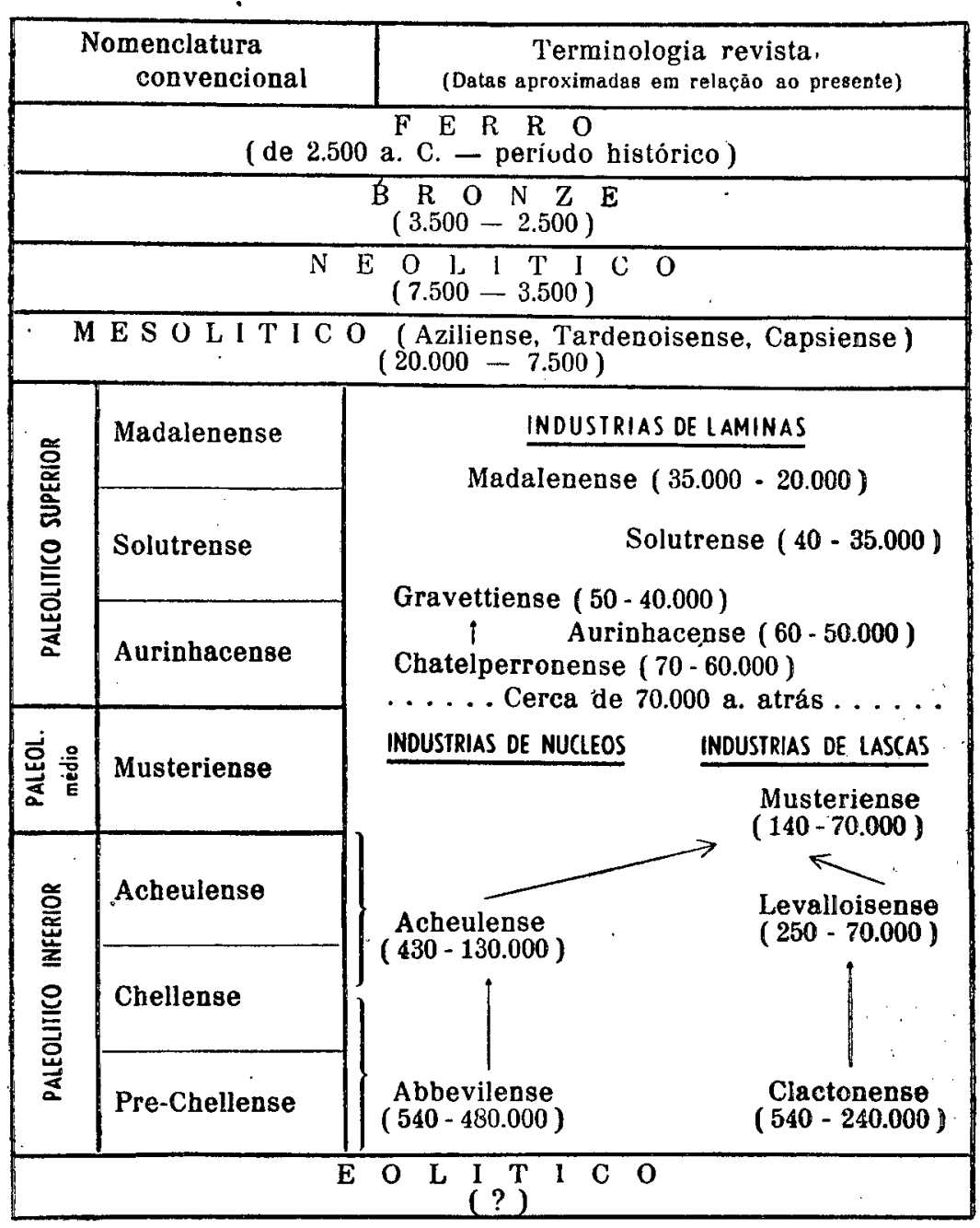

Prehistória da Europa ocidental (Garrod, Zeuner, Braidwood et al., apod M. J. Herskovits, Man and His Works, N. Y. 1949, p. 120) 
turas em grande escala que nascem as leis e a organização social, a regimentação militar, uma escravatura estatal, que constituem a base das novas civilizações, nas regiões referidas; daí a nova cultura difunde-se para a Europa.

Evolução semelhante à do Oriente próximo, norte da Africa e Europa, registra-se no Vale do rio Indus, na fndia, como no do rio Uang-Ho, na China, e nas áreas de regadio da MesoAmérica e do Perú com as grandes civilizações tolteca, azteca, inca e maia, de tal maneira que, para alguns pré-historiadores, verificar-se-ia uma conexão por assim dizer determinística ou evolutiva entre as chamadas sociedades hidráulicas e, de outra banda, a urbanização, os governos militaristas, teocráticos e despóticos que existiram nos mencionados focos do Velho e do Nôvo Mundo e se prolongaram aos temos históricos (39).

E' necessário não supor que em tais casos haja operado realmente um determinismo mesológico. A propósito dêsse dificultoso problema de uma teoria explicativa de fatos històricamente recorrentes em meios semelhantes, Kroeber adverte que

"é evidente, em princípio, que nenhum mero fator mesológico, nenhum fator populacional sòzinho, nem uma combinação dos dois, bastará para explicar efetivamente uma situação cultural. E' preciso que haja também um fator cultural, interagindo com os demais: especificamente, as condições da cultura local quando a situação surge".

E mostra que nem um dado meio natural ou determinada denstdade demográfica poderia, por si, induzir ao Homem musteriense, nos primórdios do paleolítico, a tornar-se um agricultor ou a construir cidades. Do mesmo modo, nas baixadas periòdicamente inundadas do Egito e da Mesopotâmia a custo se originaria a agricultura sem a interferência de um fator cultural, consistindo em costumes, em valores, em ambições. Mas, desde que uma sociedade de lavradores, pequenos lavradores familiais, houvesse desenvolvido hábitos de cooperação ativa e pudesse construir diques e canais comunais para a regulação do regadio para além da capacidade de lares que trabalhassem independentes, essas mesmas áreas inundadas e fertilizadas sazonalmente pelo humus carreado pelas enchentes poderiam passar a produzir o dôbro e o triplo. Com a alimentação aumen-

(39). - Julian H. Steward, in Las Civilizaciones Antiguas del Viejo Mundo $y$ de America, Union Panamericana, Washington D. C., 1955, p. 65. 
tada e produzida com regularidade, a população cresceria se nenhum fator, como as epidemias, as catástrofes, as guerras, o impedisse; em tais condições as colônias formadas de poucas famílias dispersas teriam se tornado em aldeias e alcançariam as condições de se transformarem nas primeiras cidades (40).

Atingida tal fase, estava criado o substrato social e cultural para a terceira grande etapa do desenvolvimento da $\mathrm{Hu}-$ manidade, a revolução industrial da idade moderna, desenrolada em uma série cumulativa de fases para as quais contribuiram os descobrimentos de novas terras e gentes, as descobertas e invenções, o desdobrar do saber e a sistematização mais rigorosa do pensamento.

Todo êsse processo é como ficou indicado, eminentemente cultural, produto peculiar e original da natureza humana $e_{\text {, }}$ como tal, uma obra da liberdade e da razão.

THALES DE AZEVEDO

da Universidade da Bahia 